\title{
Prognostic value of continuous electroencephalographic recording in full term infants with hypoxic ischaemic encephalopathy
}

\author{
D Wertheim, E Mercuri, JC Faundez, M Rutherford, D Acolet, L Dubowitz
}

\begin{abstract}
The prognostic value of early neonatal continuous electroencephalographic recordings in hypoxic ischaemic encephalopathy was evaluated. Thirty seven full term infants with hypoxic ischaemic encephalopathy were studied. The electroencephalogram (EEG) was recorded using four or eight channel Oxford Medilog recorders and was started as soon as possible after birth. The recordings were initially visually analysed and divided into four categories: three in relation to the grade of discontinuity of the background activity (continuous, discontinuous, and maximum depression) and an additional fourth category to include status epilepticus.

The EEGs with discontinuous activity were then analysed by computer to obtain a more objective assessment of discontinuity. The results were related to neurological outcome. Continuous background activity was associated with a normal outcome in all but the three infants who had continuous, but asymmetrical EEGs and who developed contralateral hemiplegia. In the eight infants with discontinuous activity, the outcome appeared to be related to the grade of continuity and the presence of clear convulsions on the EEG. The 10 infants with maximum depression and status epilepticus had severe impairment.

These preliminary results suggest that continuous recording of EEGs could be used routinely in term infants with hypoxic ischaemic encephalopathy. Computer analysis can improve the value of this technique, allowing the identification of infants who might benefit from early therapeutic intervention.

(Arch Dis Child 1994; 71: F97-F102)
\end{abstract}

Department of

Paediatrics and

Neonatal Medicine,

Royal Postgraduate

Medical School,

Hammersmith

Hospital,

Du Cane Road,

London W12 ONN

D Wertheim

E Mercuri

JC Faundez

M Rutherford

D Acolet

L Dubowitz

Correspondence to:

Dr Dubowitz.

Accepted 24 May 1994
Hypoxic ischaemic encephalopathy is a major cause of non-progressive neurological handicaps in children. An improvement in perinatal care and diagnosis has increased the survival rate of newborn infants with hypoxic ischaemic encephalopathy, but the prediction of outcome remains difficult. The establishment of sensitive indicators of outcome in the first few hours after birth have become of major importance as a means for selecting patients for possible early therapeutic intervention.

Previous studies have shown that normal background activity on the electroencephalo- gram (EEG) in the first week of life is a reliable indicator of a good prognosis in these infants. $^{1-4}$ Those whose EEG shows mild abnormalities in background activity that resolve within five to seven days after birth also have a good prognosis, ${ }^{1-4}$ whereas marked or maximum depression are usually suggestive of later neurological handicap. ${ }^{4-6}$ There are no reports so far on the use of continuous EEG recordings in infants with hypoxic ischaemic encephalopathy. This method has been shown to be suitable for monitoring neonatal EEGs ${ }^{78}$ and has several advantages: it does not necessitate transport of the infant, the equipment does not interfere with the routine care of sick infants, and there are fewer technical problems. The long duration of the continuous recordings also enables spontaneous changes in activity on the EEG to be monitored and the effect of treatment evaluated. ${ }^{9-12}$

The aim of this study was to evaluate the prognostic value of continuous recording of EEGs in the early neonatal period in term infants with hypoxic ischaemic encephalopathy by comparing the results from visual or computer assessment of the EEGs with neurological outcome.

\section{Subjects and methods}

This study was approved by the research ethics committee of the Royal Postgraduate Medical School. Infants were recruited into the study if they met the following criteria: neurologically abnormal in the first 48 hours of life; evidence of fetal distress - that is, meconium stained liquor or type II dips or bradycardia on the cardiotocograph, or both; and Apgar score less than 5 at five minutes. Infants with congenital infection, congenital brain malformations, or proved metabolic disorders were excluded. The grade of encephalopathy was scored according to Sarnat and Sarnat. ${ }^{1}$ The study consisted of 37 infants ( 19 boys, 18 girls) born at or referred to the Hammersmith or Queen Charlotte's Hospital between 1987 and 1993. The gestational age of the infants included in the study ranged from 37 to 42 weeks.

The EEG was continuously recorded on a four or eight channel Oxford Medilog recorder from $\mathrm{F}_{4} \mathrm{P}_{4}$ and $\mathrm{F}_{3} \mathrm{P}_{3}$ for the four channel recorders and $\mathrm{F}_{4} \mathrm{C}_{4}, \mathrm{C}_{4} \mathrm{P}_{4}, \mathrm{~F}_{3} \mathrm{C}_{3}$, and $\mathrm{C}_{3} \mathrm{P}_{3}$ for the eight channel recorders. Silver/silver chloride electrodes were applied with collodion and the interelectrode impedances were less than $5 \mathrm{k}$ Ohms. A time constant of 0.3 seconds was used. The four channel recorders were used as previously described. ${ }^{8}$ Recordings were 
Table 1 Classification of EEGs in relation to neonatal clinical data.

\begin{tabular}{|c|c|c|c|c|c|c|c|c|c|c|c|c|c|c|c|}
\hline $\begin{array}{l}\text { Patient } \\
\text { No }\end{array}$ & EEG & Symmetry & Fetal distress & Delivery & $\begin{array}{l}G A \\
\text { (weeks) }\end{array}$ & $\begin{array}{l}\text { Birh } \\
\text { weight } \\
\text { (g) }\end{array}$ & $\begin{array}{l}\text { Apgar } \\
\text { score }\end{array}$ & Intubation & $\begin{array}{l}\text { Grade } \\
\text { hypoxic } \\
\text { ischaemic } \\
\text { encephalopathy }\end{array}$ & $p H$ & $B P$ & Fits & $\begin{array}{l}\begin{array}{l}\text { Onset } \\
\text { (hours) }\end{array} \\
\text { hell }\end{array}$ & $\begin{array}{l}\text { Anticonvulsant } \\
\text { drugs }\end{array}$ & Other drugs \\
\hline 1 & $\underset{A}{\text { Normal }}$ & $\mathbf{s}$ & $\begin{array}{l}\text { Bradycardia, } \\
\text { CTG late dec }\end{array}$ & FOR & 42 & 3090 & $0 \cdot 1,4$ & + & 1 & $\mathbf{N}$ & $\mathbf{N}$ & & & & Pancuronium \\
\hline 2 & $\underset{A}{\text { Normal }}$ & $\mathbf{s}$ & $\begin{array}{l}\text { Bradycardia, } \\
\text { meconium }\end{array}$ & E-LSCS & 42 & 3174 & 3,10 & + & 1 & $\mathbf{N}$ & & & & & \\
\hline 3 & $\underset{A}{\text { Normal }}$ & $\mathbf{s}$ & $\begin{array}{l}\text { Bradycardia, } \\
\text { CTG late dec }\end{array}$ & E-LSCS & 38 & 3360 & 5,9 & - & 1 & $\mathbf{N}$ & & & & & \\
\hline 4 & $\underset{A}{\text { Normal }}$ & s & Meconium & SVD & 41 & 3870 & 8,9 & - & 2 & ^ & $\mathbf{N}$ & & & & $\begin{array}{l}\text { Morphine, } \\
\text { pancuronium }\end{array}$ \\
\hline 5 & $\underset{A}{\text { Normal }}$ & s & $\begin{array}{c}\text { Bradycardia, } \\
\text { meconium }\end{array}$ & E-LSCS & 37 & 3650 & 3,6 & + & 1 & $\mathbf{N}$ & $\mathbf{N}$ & & & & \\
\hline 6 & $\underset{A}{\text { Normal }}$ & $\mathbf{s}$ & Meconium & SVD & 40 & 2980 & 3,7 & + & 1 & ^ & $\mathbf{N}$ & & & & $\begin{array}{l}\text { Morphine, } \\
\text { pancuronium }\end{array}$ \\
\hline 7 & $\underset{A}{\text { Normal }}$ & s & $\begin{array}{c}\text { Bradycardia, } \\
\text { meconium }\end{array}$ & SVD & 41 & 2470 & 4,4 & + & 1 & ^ & $\mathbf{N}$ & & & & \\
\hline 8 & $\underset{A}{\text { Normal }}$ & s & Tachycardia & SVD & 37 & 3380 & 4,4 & + & 1 & * & $\mathbf{N}$ & & & & \\
\hline 9 & $\underset{B}{\text { Normal }}$ & $\mathbf{s}$ & CTG late dec & K1-FOR & 42 & 3490 & 5,5 & - & 1 & * & $\mathbf{N}$ & & & & \\
\hline 10 & $\begin{array}{l}\text { Normal } \\
\text { B }\end{array}$ & $\mathbf{s}$ & $\begin{array}{l}\text { Meconium, } \\
\text { CTG dec }\end{array}$ & E-LSCS & 40 & 4015 & 2,8 & + & 2 & * & $\mathbf{N}$ & $\begin{array}{l}\text { Jerky } \\
\text { movements }\end{array}$ & & & $\begin{array}{l}\text { Morphine, } \\
\text { pancuronium }\end{array}$ \\
\hline 11 & $\underset{B}{\text { Normal }}$ & $\mathbf{s}$ & $\begin{array}{l}\text { Meconium, } \\
\text { CTG early dec }\end{array}$ & SVD & 40 & 4255 & 3,4 & + & 1 & $\mathbf{N}$ & $\mathbf{N}$ & & & & Dopamine \\
\hline 12 & $\begin{array}{l}\text { Normal } \\
\text { B }\end{array}$ & $\mathbf{s}$ & CTG late dec & E-LSCS & 41 & 3930 & 0,0 & + & 2 & $\mathbf{N}$ & $\mathbf{N}$ & Clonic & Day 2 & $\mathbf{P b}, \mathbf{P h}$ & \\
\hline 13 & $\begin{array}{l}\text { Normal } \\
\text { B }\end{array}$ & $\mathbf{s}$ & Meconium & SVD & 40 & 2810 & 5,7 & - & 1 & $\mathbf{N}$ & $\mathbf{N}$ & & & & \\
\hline 14 & $\begin{array}{l}\text { Normal } \\
\text { B }\end{array}$ & $\mathbf{s}$ & CTG early dec & FOR & 41 & 3500 & 9,10 & - & 2 & $\mathbf{N}$ & $\mathbf{N}$ & $\begin{array}{l}\text { Cycling, } \\
\text { clonic }\end{array}$ & 9 & $\mathrm{~Pb}, \mathrm{Ph}$ & \\
\hline 15 & $\begin{array}{l}\text { Normal } \\
B\end{array}$ & AS & $\begin{array}{l}\text { Meconium, } \\
\text { CTG late dec }\end{array}$ & VENT & 38 & 1700 & 4,8 & - & 2 & $\mathbf{N}$ & $\mathbf{N}$ & Clonic & 10 & $\mathbf{P h}$ & \\
\hline 16 & $\stackrel{\text { Normal }}{\mathrm{C}}$ & AS & Bradycardia & FOR & 40 & 3304 & 9,10 & - & 2 & $\mathrm{~N}$ & $\mathrm{~N}$ & $\begin{array}{l}\text { Jerky } \\
\text { movements }\end{array}$ & 6 & $\mathrm{~Pb}, \mathrm{Ph}$ & \\
\hline 17 & $\underset{C}{\text { Normal }}$ & AS & CTG early dec & FOR & 41 & 3650 & 6,10 & - & 2 & $\mathbf{N}$ & $\mathbf{N}$ & $\begin{array}{l}\text { Dusky } \\
\text { episode }\end{array}$ & 1.5 & $\mathrm{~Pb}$ & \\
\hline 18 & $\begin{array}{l}\text { Normal } \\
\mathrm{C}\end{array}$ & $s$ & Meconium & FOR & 40 & 3250 & 8,10 & - & 2 & $\mathbf{N}$ & $\mathbf{N}$ & $\begin{array}{l}\text { Tonic- } \\
\text { clonic }\end{array}$ & 48 & $\mathrm{~Pb}$ & \\
\hline 19 & $\underset{\mathrm{C}}{\text { Normal }}$ & $\mathbf{s}$ & Bradycardia & SVD & 40 & 3740 & 5,10 & - & 2 & $\mathbf{N}$ & $\mathbf{N}$ & $\begin{array}{l}\text { Tonic- } \\
\text { clonic }\end{array}$ & 48 & $\mathrm{~Pb}$ & \\
\hline 20 & Discontinuous & $s$ & CTG early dec & SVD & 40 & 2285 & 7,8 & + & 2 & * & $\mathbf{N}$ & $\begin{array}{l}\text { Not } \\
\text { described }\end{array}$ & 6 & $\mathrm{~Pb}$ & Dopamine \\
\hline 21 & Discontinuous & $\mathbf{s}$ & CTG early dec & E-LSCS & 40 & 3150 & 4,4 & + & 2 & $\mathbf{N}$ & $\mathbf{N}$ & $\begin{array}{l}\text { Jerky } \\
\text { movements }\end{array}$ & Day 1 & $\mathrm{~Pb}, \mathrm{Ph}$ & \\
\hline 22 & $\begin{array}{l}\text { Discontinuous } \\
\text { A }\end{array}$ & $\mathbf{s}$ & Bradycardia & E-LSCS & 40 & 3590 & 0,5 & + & 2 & * & $\mathbf{N}$ & Cycling & $3-4$ & $\mathrm{Ph}$, clon & \\
\hline 23 & $\begin{array}{l}\text { Discontinuous } \\
\text { C }\end{array}$ & $\mathbf{s}$ & CTG early dec & SVD & 40 & 3205 & 3,9 & - & 2 & $\mathbf{N}$ & $\mathrm{N}$ & Clonic & 6 & $\mathrm{~Pb}, \mathrm{Ph}$ & \\
\hline 24 & $\begin{array}{l}\text { Discontinuous } \\
\text { C }\end{array}$ & AS & Meconium & K1-FOR & 41 & 3400 & 4,8 & - & 2 & $\mathbf{N}$ & ^ & $\begin{array}{l}\text { Tonic- } \\
\text { clonic }\end{array}$ & 7 & $\mathrm{~Pb}, \mathrm{Ph}$ & Dopamine \\
\hline 25 & $\begin{array}{l}\text { Discontinuous } \\
\text { C }\end{array}$ & s & $\begin{array}{l}\text { Meconium, } \\
\text { CTG dec }\end{array}$ & E-LSCS & 38 & 2610 & 1,4 & + & 2 & * & $\mathbf{N}$ & & & $\mathrm{Pb}$ & \\
\hline 26 & $\begin{array}{l}\text { Discontinuous } \\
\text { C }\end{array}$ & $\mathbf{s}$ & $\begin{array}{l}\text { Bradycardia, } \\
\text { CTG late dec }\end{array}$ & E-LSCS & 41 & 4252 & 0,2 & + & 2 & ^ & $\mathbf{N}$ & $\begin{array}{l}\text { Tonic- } \\
\text { clonic }\end{array}$ & 12 & $\mathrm{~Pb}, \mathrm{Ph}$ & Dopamine \\
\hline 27 & Discontinuous & $\mathbf{s}$ & CTG early dec & E-LSCS & 41 & 2650 & 1,5 & + & 2 & $\mathbf{N}$ & $\mathbf{N}$ & $\begin{array}{l}\text { Jerky } \\
\text { movements }\end{array}$ & 24 & $\mathrm{~Pb}$, diaz & \\
\hline 29 & Max. depression & S & Bradycardia & E-LSCS & 39 & 3430 & 1,5 & + & 2 & ^ & ^ & $\begin{array}{l}\text { Not } \\
\text { described }\end{array}$ & Day 2 & $\mathrm{~Pb}, \mathrm{Ph}$ & Dopamine \\
\hline 30 & Max. depression & S & Bradycardia & E-LSCS & 40 & 2354 & 3,5 & + & 3 & ^ & $\mathbf{N}$ & $\begin{array}{l}\text { Tonic- } \\
\text { clonic }\end{array}$ & 1 & $\mathrm{~Pb}, \mathrm{Ph}$ & \\
\hline 30 & Max. depression & $\mathbf{s}$ & Bradycardia & E-LSCS & 40 & 3460 & 2,2 & + & 3 & $\mathrm{~N}$ & ^ & & & & Dopamine \\
\hline 31 & Max. depression & $\mathrm{s}$ & Bradycardia & E-LSCS & 38 & 3140 & 0,2 & + & 3 & $\mathbf{N}$ & $\mathbf{N}$ & Clonic & 1 & $\mathrm{~Pb}, \mathrm{Ph}$ & Pancuronium \\
\hline 32 & Max. depression & s & CTG late dec & E-LSCS & 39 & 3800 & 2,5 & + & 2 & $\mathbf{N}$ & $\mathbf{N}$ & Clonic & 8 & $\mathrm{Ph}$, clon & Pethidine \\
\hline 34 & Max. depression & $\mathbf{s}$ & $\begin{array}{l}\text { Bradycardia, } \\
\text { CTG dec }\end{array}$ & SVD & 40 & 3050 & 0 & + & 3 & $\mathbf{N}$ & $\mathbf{N}$ & Clonic & 12 & $\mathrm{~Pb}, \mathrm{Ph}$ & \\
\hline $\begin{array}{l}35 \\
36\end{array}$ & $\underset{\mathrm{C}}{\operatorname{Max} \text { depression }}$ & $\mathbf{s}$ & $\begin{array}{l}\text { Meconium, } \\
\text { bradycardia }\end{array}$ & E-LSCS & 40 & 3190 & 0,2 & + & 3 & * & $\mathbf{N}$ & $\begin{array}{l}\text { Tonic- } \\
\text { clonic }\end{array}$ & 1 & $\mathrm{~Pb}, \mathrm{Ph}$ & \\
\hline $\begin{array}{l}35 \\
36\end{array}$ & $\begin{array}{l}\text { Status epilipticus } \\
\text { Status epilepticus }\end{array}$ & $\begin{array}{l}\text { AS } \\
\text { AS }\end{array}$ & $\begin{array}{l}\text { Bradycardia } \\
\text { Meconium }\end{array}$ & $\begin{array}{l}\text { SVD } \\
\text { SVD }\end{array}$ & $\begin{array}{l}41 \\
40\end{array}$ & $\begin{array}{l}3240 \\
3920\end{array}$ & $\begin{array}{l}3,9 \\
0,1\end{array}$ & $\begin{array}{l}+ \\
+\end{array}$ & $\begin{array}{l}2 \\
2\end{array}$ & $\stackrel{*}{N}$ & $\stackrel{N}{N}$ & $\begin{array}{l}\text { Clonic } \\
\text { Jerky } \\
\text { movement }\end{array}$ & $\begin{array}{l}32 \\
\text { Not } \\
\text { stat }\end{array}$ & $\begin{array}{l}\mathrm{Pb} \\
\mathrm{Pb}\end{array}$ & Dopamine \\
\hline 37 & Status epilepticus & & $\begin{array}{c}\text { Bradycardia, } \\
\text { meconium }\end{array}$ & E-LSCS & 42 & 4125 & 1,1 & + & 2 & * & $\mathbf{N}$ & Clonic & & $\mathrm{Pb}, \mathrm{Ph}$ & \\
\hline
\end{tabular}

Abbreviations: $A=$ no sharp waves or seizure activity; $B=$ excessive sharp waves; $C=$ electrical seizures; $S=$ symmetrical; $A S=$ asymmetrical; $C T G=$ cardiotocographic; dec=decelerations; $\mathrm{FOR}=$ forcep; $\mathrm{SVD}=$ =spontaneous vaginal delivery; $\mathrm{E}-\mathrm{LSCS}=$ emergency low caesarean section; $\mathrm{GA}=$ gestational age; $\mathrm{N}=$ normal; $\mathrm{BP}=\mathrm{blood}$ pressure; $\mathrm{Pb}=$ phenobarbitone; $\mathrm{Ph}=$ phenytoin;

started as soon as possible and lasted for at least 12 hours. All EEGs were performed using fixed gain settings on the recorders and hence when assessing recordings the term 'no discernible cerebral activity' refers to the EEG recorded in this way.

The EEGs were initially visually assessed for background continuity, amplitude, symmetry, synchrony, range of frequencies, presence or absence of excessive frequency of sharp transients or spikes, and presence or absence of frank seizure activity. We have avoided using the term 'burst suppression' because of the wide range of meanings applied to the term in published work on neonatal EEGs. ${ }^{56}$

The EEGs were divided into four main categories in relation to the continuity of the background activity: group 1, normal - normal continuity (appropriate for age), discontinuity observed only during quiet sleep state; group 2, discontinuous - EEGs described as discontinuous if for at least one hour there were periods with bursts of cerebral activity separated by low voltage intervals with no discernible cerebral activity that could not be explained as 'tracé' alternant; and group 3, maximum depression - no discernible cerebral activity for at least one hour (infants whose EEG showed some seizure activity on a maximal depression background were classified in this group); and group 4, status epilepticus.

All recordings with status epilepticus were grouped in the last category as they could not be fitted in any of the previous categories. The EEG status epilepticus was defined as continuous EEG seizure type activity in one or more channels for at least four hours, or separated only for short periods by activity with frequent sharp waves or spikes.

The first three groups were subsequently 


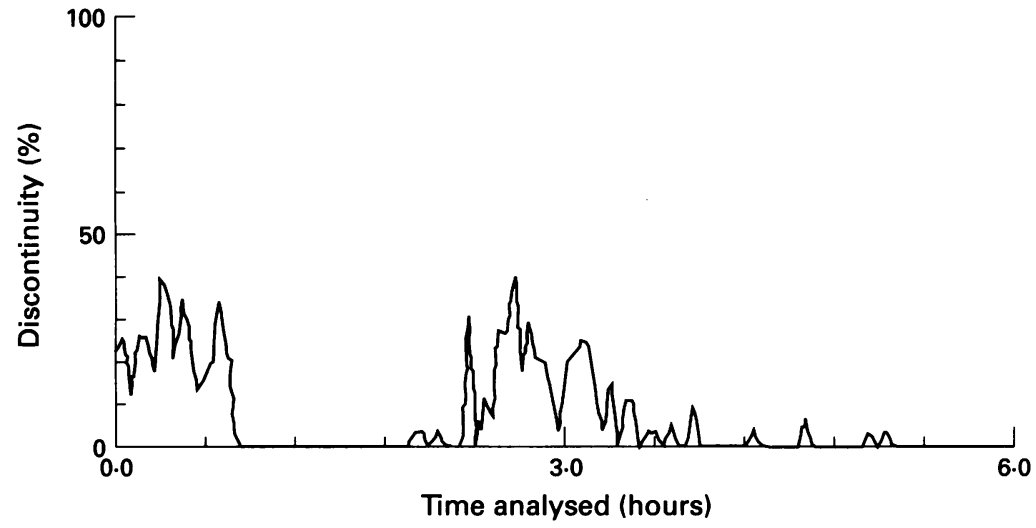

Figure 1 Computer analysis of an EEG with more than $50 \%$ of epochs of continuous background activity. tinuous with no continuous activity epochs and no cycling of discontinuity.

The possible effect of clinical variables, such as anticonvulsants or other drugs, blood pressure, or $\mathrm{pH}$, on the EEG were also evaluated.

\section{ASSESSMENT OF OUTCOME}

Follow up clinical assessment included neurological examination and the use of Griffith developmental scales. Infants were seen at three month intervals until 1 year, at 18 months, and then yearly. A detailed neurological examination and Griffith developmental scales were performed at each visit, where possible.

divided into three subgroups: (a) no excess of sharp transients and no seizures; (b) excessive number of sharp transients; and (c) clear EEG seizures.

\section{COMPUTER ANALYSIS}

Recordings that were at any time discontinuous were also subjected to computer analysis for the first six hours of the recording. The recordings were digitised and stored on a hard disk or optical disk. The digitised EEG was then analysed by computer for discontinuity and amplitude by an off line adaptation for EEG of term infants on an on line system described previously. ${ }^{14}$ The analysis of the right and left channels of the EEG were displayed as compressed graphs, with the background discontinuity changes on the vertical axis against time on the horizontal axis. The duration of the analysis takes less than 30 minutes.

The computer analysis was used to assess the discontinuity; three one minute epochs were averaged. A completely continuous EEG had $0 \%$ discontinuity and a completely discontinuous EEG had 100\% discontinuity for each epoch. The values were plotted on a graph. The EEGs were subdivided into three groups on the basis of the percentage of epochs which showed continuous activity: (a) more than $50 \%$ continuous activity epochs: (b) less than $50 \%$ but greater than $0 \%$ continuous activity epochs; and (c) the EEG was always discon-

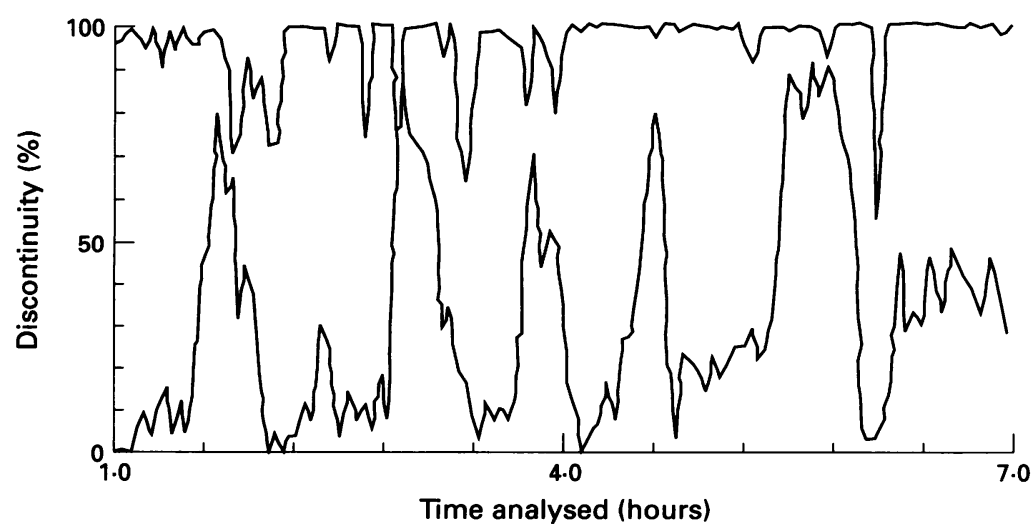

Figure 2 Computer analysis of an EEG showing a marked asymmetry between the two sides with more marked discontinuity on the left side.

\section{Results}

Table 1 summarises the details of the clinical and EEG findings.

In inborn infants EEG recordings were started as soon as possible after birth; in outborn infants they were started soon after admission. In six patients recordings started within 12 hours, in 13 between 12 and 24 hours, in seven between 24 and 48 hours, in nine within 72 hours, and the remaining two within 80 hours.

\section{EEG VISUAL ANALYSIS}

Group 1

Nineteen patients had continuous background activity, including two infants whose EEG was initially considered to be of low amplitude but clearly continuous; the EEG amplitude returned to expected levels within 12 hours of the start of the recording. Eight of 19 infants were in group 1a and seven were in group 1b, showing frequent sharp waves, asymmetrical in one of them. The remaining four had clear EEG seizures, which were asymmetrical in two.

\section{Group 2}

Discontinuous recordings were present in eight infants, five of whom also had seizure activity. One of these five had marked asymmetry of background activity and seizure frequency.

\section{Group 3}

Maximal depression was observed in seven patients. In one of the seven no activity was detected during the whole duration of the recording. The other six showed seizure activity.

\section{Group 4}

Three patients had EEG status epilepticus; in two it was focal.

\section{COMPUTER ANALYSIS}

Seven of the eight recordings with discontinuous background activity were analysed by computer. The eighth recording was unsuitable because of a large number of artefacts. In 


\begin{tabular}{|c|c|c|c|c|c|c|c|c|c|}
\hline & \multirow[b]{2}{*}{$E E G$} & \multirow[b]{2}{*}{ Motor impairment } & \multicolumn{6}{|c|}{ Griffith mental developmental scales } & \multirow[b]{2}{*}{ Comments } \\
\hline & & & Locomotor & $\begin{array}{l}\text { Personall } \\
\text { social }\end{array}$ & $\begin{array}{l}\text { Hearing/ } \\
\text { speech }\end{array}$ & $\begin{array}{l}\text { Eye-hand } \\
\text { coordination }\end{array}$ & Performance & $\begin{array}{l}\text { Practical } \\
\text { reasoning }\end{array}$ & \\
\hline 1 & $\begin{array}{l}\text { Normal } \\
A\end{array}$ & Normal & 106 & 112 & 100 & 100 & 108 & & \\
\hline 2 & $\begin{array}{l}\text { Normal } \\
\text { A }\end{array}$ & Normal & 125 & 133 & 150 & 108 & 108 & 150 & \\
\hline 3 & Normal & Normal & 109 & 118 & 109 & 109 & 100 & & \\
\hline 4 & $\begin{array}{l}\text { Normal } \\
A\end{array}$ & Normal & 106 & 112 & 100 & 100 & 108 & & \\
\hline 5 & $\begin{array}{l}\text { Normal } \\
\text { A }\end{array}$ & Normal & & & & & & & Not available \\
\hline 6 & Normal & Normal & & & & & & & Not available \\
\hline 7 & $\begin{array}{l}\text { Normal } \\
A\end{array}$ & Normal & 150 & 126 & 120 & 166 & 120 & & \\
\hline 8 & Normal & Normal & 106 & 112 & 96 & 100 & 106 & & \\
\hline 9 & $\begin{array}{l}\text { Normal } \\
B\end{array}$ & Normal & 138 & 156 & 156 & 133 & 122 & & \\
\hline 10 & $\underset{B}{\text { Normal }}$ & Normal & 128 & 135 & 124 & 132 & 128 & & \\
\hline 11 & $\begin{array}{l}\text { Normal } \\
\text { B }\end{array}$ & & & & & & & & Died \\
\hline 12 & $\begin{array}{l}\text { Normal } \\
\mathrm{B}\end{array}$ & Normal & 127 & 133 & 133 & 121 & 121 & 133 & \\
\hline 13 & $\begin{array}{l}\text { Normal } \\
\mathrm{B}\end{array}$ & Normal & 98 & 106 & 98 & 90 & 98 & & \\
\hline 14 & $\begin{array}{l}\text { Normal } \\
B\end{array}$ & $\begin{array}{l}\text { Ocular apraxia developmental } \\
\text { delay }\end{array}$ & 105 & 111 & 105 & 94 & 88 & 116 & \\
\hline 15 & $\begin{array}{l}\text { Normal } \\
B\end{array}$ & Mild hemiplegia & 116 & 116 & 108 & 108 & 108 & & \\
\hline 16 & Normal & Hemiplegia & 96 & 94 & 100 & 94 & 96 & & \\
\hline 17 & Normal & Hemiplegia & 101 & 103 & 91 & 103 & 101 & 101 & \\
\hline 18 & Normal & Normal & 122 & 116 & 94 & 108 & 98 & & \\
\hline 19 & Normal & Normal & 116 & 101 & 110 & 101 & 120 & & \\
\hline 20 & Discontinuous & Normal & 83 & 88 & 83 & 105 & 108 & & \\
\hline 21 & Discontinuous & Normal & 87 & 81 & 70 & 70 & 70 & & \\
\hline 22 & $\begin{array}{l}\text { Discontinuous } \\
\mathrm{A}\end{array}$ & Quadriplegia & na & na & na & na & na & & \\
\hline 23 & Discontinuous & Quadriplegia & na & na & na & na & na & & \\
\hline 24 & Discontinuous & Hemiplegia & na & na & na & na & na & & \\
\hline 25 & Discontinuous & Athetoid CP & & & & & & & $\begin{array}{l}\text { Incomplete estimated } \\
\text { quotient: } 50\end{array}$ \\
\hline 26 & $\begin{array}{l}\text { Discontinuous } \\
\text { C }\end{array}$ & Increased tone, microcephaly & na & na & na & na & na & & \\
\hline 27 & Discontinuous & Athetoid CP & & & & & & & $\begin{array}{l}\text { Incomplete estimated } \\
\text { quotient: } 70-80\end{array}$ \\
\hline 28 & Max.depression & Severe quadriplegia & na & na & na & na & na & & \\
\hline 29 & Max. depression & & & & & & & & Died \\
\hline 30 & Max. depression & & & & & & & & Died \\
\hline 31 & $\underset{C}{\text { Max. depression }}$ & & & & & & & & Died \\
\hline 32 & $\underset{C}{\text { Max. depression }}$ & Developmental delay & na & na & na & na & na & & \\
\hline $\begin{array}{l}33 \\
34\end{array}$ & Max. depression & & & & & & & & Died \\
\hline 34 & Max. depression & Severe developmental delay & na & na & na & na & na & & \\
\hline $\begin{array}{l}35 \\
36\end{array}$ & Status epilepticus & Quadriplegia epilepsy & na & na & na & na & na & & \\
\hline 36 & Status epilepticus & $\begin{array}{l}\text { Severe developmental delay, } \\
\text { hemiplegia }\end{array}$ & & & & & & & $\begin{array}{l}\text { Incomplete estimated } \\
\text { quotient: }<50\end{array}$ \\
\hline 37 & Status epilepticus & Quadriplegia epilepsy & na & na & na & na & na & & \\
\hline
\end{tabular}

Abbreviations: $\mathrm{A}=$ no sharp waves or seizure activity; $\mathrm{B}=$ excessive sharp waves; $\mathrm{C}=$ electrical seizures; $\mathrm{CP}=$ cerebral palsy; and na=not applicable.

four of these seven recordings more than $50 \%$ of the epochs were continuous (fig 1), in two less than $50 \%$ of epochs were continuous, and one of these was asymmetrical (fig 2). In one recording there was no continuous activity epoch.

CLINICAL VARIABLES

Phenobarbitone, alone or in association with phenytoin or other drugs, was used in seven patients in group 1, in six patients in group 2, in four of group 3, and in all three patients in group 4 (table 1 ).

Mild acidosis and hypotension, corrected within one or two hours, occurred with variable frequency in all the groups (table 1).

OUTCOME

The duration of the follow up examination ranged from six months to six years. Table 2 gives the clinical details.

\section{EEG group 1}

One of the 19 infants with normal background activity on the EEG died from unrelated respiratory problems. Fourteen had a normal outcome. Seven of these 14 infants had 
excessive sharp waves and three had electrical seizures. Four infants had an abnormal outcome. One of the four with an ocular motor apraxia had excessive sharp waves. Three children developed a hemiplegia and, although their background activity was continuous on both sides, they showed asymmetry either in amplitude or in the presence of abnormal transients and seizures, the more abnormal side being contralateral to the subsequent hemiplegia. On magnetic resonance imaging two of these children had an infarction in the territory of the middle cerebral artery; the third had a thalamic lesion with adjacent hemispheric infarction.

\section{EEG group 2}

In the group of eight infants with discontinuous activity seven recordings could be analysed by computer; four infants had completely continuous activity for more than $50 \%$ of the epochs analysed. Two of these had no motor impairment and the other two developed athetoid cerebral palsy.

In two infants the amount of continuity was less than $50 \%$ of the epochs; one of these is only 6 months old but he has abnormalities of tone and is microcephalic, whereas the other infant has a hemiplegia with mild global delay and specific perceptual difficulties. Seizures were present in four children with an abnormal outcome, but were absent in the two with normal outcome.

The seventh infant, who had no continuous epochs and no cycling of continuity, is quadriplegic and severely mentally retarded. Thus either the presence of EEG seizures or the absence of continuous epochs was associated with a less favourable outcome. The child whose EEG was not analysed by computer developed quadriplegia.

\section{EEG group 3}

Three of the seven infants in this group died in the first week of life. All four surviving infants have severe motor and mental impairment.

\section{EEG group 4}

All three infants with EEG status epilepticus have severe motor and mental impairment.

\section{Discussion}

Previous studies of neonatal EEGs in term infants with evidence of birth asphyxia have shown that background activity is an important prognostic indicator. ${ }^{1-4}$ They showed that marked or maximal depression was associated with later handicaps, although mild EEG abnormalities which resolved in seven days were related to a good outcome. In these studies only standard multichannel EEG recordings were used and no systematic quantitative evaluation was applied. They also used the evolution of the EEG as a prognostic indicator. Our aim in this study was to use the earliest EEG available to evaluate recordings which might be used for the selection of infants for intervention and also to apply a more quantitative evaluation of discontinuous recordings.

We were able to show that not only were our results equally reliable as published data, in spite of the small number of channels used, but that quantification, which is more easily performed by continuous analysis, was better at grading the continuity of the EEG than visual analysis alone. Our results confirmed previous findings of a normal outcome in infants with a good background activity, irrespective of the presence of convulsions. We were able to show, however, that asymmetry in the background activity was also a significant prognostic indicator. Three children had an asymmetrical though continuous background, and all developed hemiplegia.

In parallel with previous studies we have also confirmed a poor prognosis associated with maximal EEG depression but, in addition, we noted a similarly poor prognosis in infants with status epilepticus, in whom the background EEG activity could not be classified.

In the eight children with discontinuity, computer analysis allowed us to grade the severity of discontinuity in seven and relate it to outcome. Two children in this group had a normal outcome, one had increased tone, and four had severe motor deficits. It is of interest that the two normal children in this group were the only children without any seizure activity on the EEG. Although the group is small, it is possible that the absence of seizure activity in this group might be a good prognostic sign. Of the four children with motor impairment, in three there were some continuous epochs and these had a less severe intellectual impairment. The one infant in whom no continuous epoch was recorded was quadriplegic and severely mentally retarded. The number of patients is too small to reach definite conclusions about whether the amount of discontinuity relates to the severity of outcome, but the complete absence of any continuous epochs, which is not recognisable by visual analysis, suggests that it might be a poor prognostic sign equal to that of maximal depression.

There has been concern that anticonvulsant treatment could modify the EEG. ${ }^{15}$ The degree to which anticonvulsant drugs can modify EEG activity is not clear, however. ${ }^{16}$ In this study we did not have enough children in whom the EEG was recorded before the treatment to assess the possible effect of the drug. It is of interest, however, that from the prognostic point of view, treatment with phenobarbitone did not interfere with the EEG in those infants with normal background activity. This is illustrated by six patients who were receiving phenobarbitone and still showed full continuity. Five of the six had a loading dose of $20 \mathrm{mg}$, followed by a maintenance dose of $10 \mathrm{mg}$; one had a loading dose of $10 \mathrm{mg}$ only. The EEG was started before or within 0-24 hour of the loading dose. As this study was not set up to evaluate prospectively the effect of anticonvulsant drugs, we have no 
accurate timing of drug administration or concentrations of anticonvulsant drugs in relation to the EEG. Thus the acute effect cannot be evaluated. In the seven patients in group 2 the discontinuity remained invariable; it is possible that in these patients phenobarbitone could have affected the number of continuity epochs, but as all these children had an abnormal outcome, the interference is probably negligible.

Although this study has already shown the usefulness of continuous EEG and computer analysis, further prospective work will be needed to answer a number of additional questions, in particular to establish whether EEG recordings performed in the first 24 hours of life are equally prognostic to those performed later. It will also be necessary to evaluate prospectively the acute and prolonged effect of phenobarbitone and other drugs which can be monitored by on line analysis.

1 Sarnat HB, Sarnat MS. Neonatal encephalography following fetal distress. Arch Neurol 1976; 33: 696-705.

2 Watanabe K, Miyazaki S, Hara K, Hakamada S. Behavioral state cycle, background EEGs and prognosis of newborns with perinatal hypoxia. Electroencephalogr Clin Neurophysiol 1980; 49: 618-25.

3 Bjerre I, Hellstrom-Westas L, Rosen I, Svenningsen N. Monitoring of cerebral function after severe asphyxia in infancy. Arch Dis Child 1983; 58: 997-1002

4 Takeuchi T, Watanabe K. The EEG evolution and neuro- logical prognosis of perinatal hypoxia neonates. Brain Dev 1989; 11: 115-20.

5 Holmes G, Rowe J, Hofford J, Schmidt R, Testa M, Zimmerman A. Prognostic value of the electroencephalogram in neonatal asphyxia. Electroencephalogr Clin Neurophysiol 1982; 53: 60-72.

6 Grigg-Damberger M, Coker SB, Halsey CL, Anderson CL Neonatal burst suppression: its developmental significance. Pediatr Neurol 1989; 5: 84-92.

7 Eyre JA, Oozeer RC, Wilkinson AR. Diagnosis of neonatal seizure by continuous recording and rapid analysis of the electroencephalogram. Arch Dis Child 1983; 58: 785-90.

8 Connell JA, Oozeer $\mathrm{R}$, Dubowitz V. Continuous 4-channel EEG monitoring: a guide to interpretation with normal values in preterm infants. Neuropediatrics 1987; 18: values in

9 Greisen G, Pryds O, Rosen I, Lou H. Poor reversibility of EEG abnormality in hypotensive, preterm neonates. Acto Paediatr Scand 1988; 77: 785-90.

10 Murdoch Eaton DG, Wertheim D, Oozeer R, Royston P, Dubowitz L, Dubowitz V. The effect of pethidine on the neonatal EEG. Dev Med Child Neurol 1992; 34; 155-63.

11 Bell AH, Greisen G, Pryds O. Comparison of the effects of phenobarbitone and morphine administration on EEG activity in preterm babies. Acta Paediatr 1993; 82: 35-9.

12 Murdoch Eaton DG, Wertheim D, Oozeer R, Dubowitz LMS, Dubowitz V. Reversible changes in cerebral funcL.MS, Dubowitz V. Reversible changes in cerebral funcPaediatr (in press).

13 Pezzani C, Radvanyi-Bouvet MF, Pelier JP, Monod N. Neonatal electroencephalography during the first twentyfour hours of life in full-term newborn infants Neuropediatrics 1986; 17: 11-8.

14 Wertheim DFP, Murdoch Eaton DG, Oozeer RC, et al. A new system for cotside display and analysis of the preterm neonatal electroencephalogram. Dev Med Child Neurol 1991; 33: 1080-6.

15 Moussalli-Salefranque F, Mises J, Plouin P. Significance of discontinuous traces in the full-term newborn infant. Rev discontinuous traces in the full-term newborn infant.

16 Staudt F, Scholl ML, Coen RW, Bickford RB. Phenobarbital therapy in neonatal seizures and the prognostic value of the EEG. Neuropediatrics 1982; 13: 24-33. 